\title{
Late Quaternary history of Lammefjorden, north-west Sjælland, Denmark
}

\author{
Ole Bennike ${ }^{* 1}$, Peter Roll Jakobsen', Jakob Walløe Hansen² \\ 'Geological Survey of Denmark and Greenland (GEUS), Aarhus, Denmark. ${ }^{2}$ UNESCO Global Geopark Odsherred, Nykøbing, Denmark.
}

\begin{abstract}
Lammefjorden is a reclaimed fjord in north-west Sjælland, Denmark. Sediment cores from the area were collected to study its development after the last deglaciation, in particular the sea-level history. Late glacial and Early Holocene lake and bog deposits occur below marine deposits. Sparse late glacial fossil assemblages indicate tree-less environments with dwarf-shrub heaths. Early Holocene deposits contain remains of Betula sec. Albae sp. and Pinus sylvestris, which indicate open forests. The wetland flora comprised the calciphilous reed plant Cladium mariscus and the water plant Najas marina. Marine gyttja from basins is characterised by sparse benthic faunas, probably due to high sedimentation rates. In some areas, shell-rich deposits were found, with large shells of Ostrea edulis, indicative of high summer temperatures, high salinity and strong tidal currents. A marine shell dated to $6.7 \mathrm{cal}$. ka provides a minimum age for the marine transgression of Lammefjorden.
\end{abstract}

\section{Introduction}

In 1873, a large project was initiated to reclaim Lammefjorden in north-west Sjælland (Fig. 1), and today Lammefjorden is one of the largest reclaimed areas in north-west Europe. The geology of the Lammefjorden region was mapped by the Geological Survey of Denmark in the late 1890s (Rørdam \& Milthers 1900). Shell samples from Holocene-raised marine deposits were analysed and several of them contained shells of Ostrea and Tapes. These bivalves no longer live in the region and their former presence was taken to indicate stronger tidal currents than at present (Rørdam \& Milthers 1900, p. 101). It was also noted that in situ Quercus stumps and peat deposits were found below marine deposits. Both marine and non-marine deposits were referred to as 'alluvium' (Holocene), but a more precise age could not be determined.

Madsen et al. (1900) described a large Stone Age shell midden near Fårevejle in the inner part of Lammefjorden (Fig. 1). The mollusc fauna comprised shells of Ostrea and Tapes. The Ostrea shells were up to $130 \mathrm{~mm}$ long - a large size pointing to favourable conditions. Artefacts mainly belonged to the late Mesolithic Ertebølle culture. The shell midden was located at an elevation of 3.5 to $5 \mathrm{~m}$ a.s.l., just above the marine limit at c. $3.5 \mathrm{~m}$ a.s.l. (Mertz 1924).

In the 1920s and 1930s, archaeologist Erik Westerby tried to locate submarine, pre-Ertebølle settlements in Denmark. Westerby (1933) searched for such sites in reclaimed areas now situated below sea level and found

\author{
*Correspondence: obe@geus.dk \\ Received: 19 Feb 2020 \\ Accepted: 23 Apr 2020 \\ Published: 25 June 2020
}

Keywords: Lammefjorden, Sjælland, Quaternary, late glacial, Holocene, macrofossils

\begin{abstract}
Abbreviations:
a.s.I.: above sea level

b.s.l.: below sea level

RSL: relative sea level

UNESCO: United Nations Educational,

Scientific and Cultural Organization

GEUS Bulletin is an open access, peerreviewed journal published by the Geological Survey of Denmark and Greenland (GEUS). This article is distributed under a CC-BY 4.0 licence, permitting free redistribution, and reproduction for any purpose, even commercial, provided proper citation of the original work. Author(s) retain copyright.
\end{abstract}

Edited by: Catherine Jex (GEUS, Denmark)

Reviewed by: Jonathan Lewis (Loughborough University, UK) and one anonymous reviewer

Funding: See page 5

Competing interests: None declared

Additional files: See page 5 


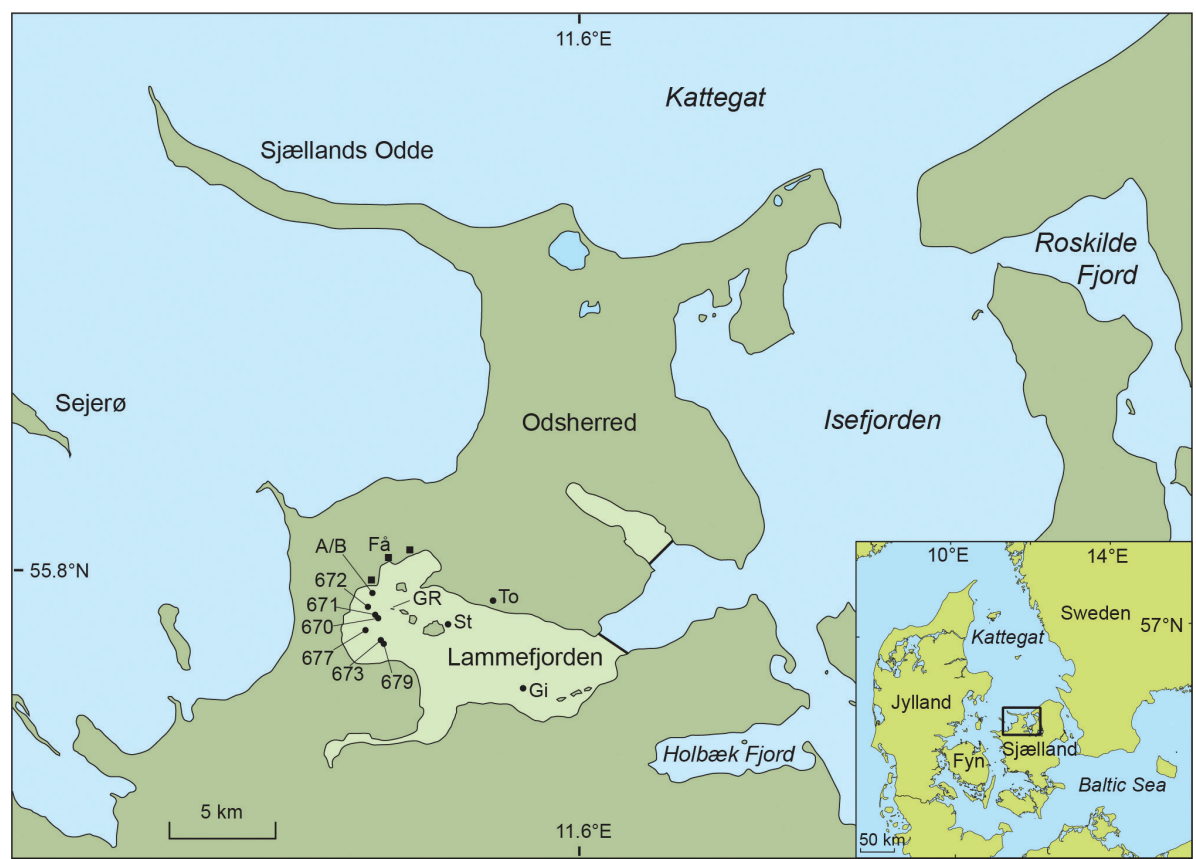

- Ertebølle site $\square$ Reclaimed area
Fig. 1 Map of north-west Sjælland showing the reclaimed area of Lammefjorden; 670-679 denote core sites for cores 197.670 to 197.679 . A/B: Open sections sampled in 2019. GR: Georadar profile 1, see Fig. 3 for data. Få: Fårevejle. To: Toftevang. St: Storø. Gi: Gislinge Lammefjorden. settlements at two sites in Lammefjorden. They belong to what is now referred to as the Kongemose culture. One of the sites near Gislinge (Fig. 1), located at $2.5 \mathrm{~m}$ b.s.l., was excavated by Mathiassen (Troels-Smith 1942) and by Simonsen (1946). Christensen (1994) and Christensen \& Andreasen (1999) discussed RSL changes in the region. Dating of charcoal from the Gislinge settlement places it in the Early Kongemose culture (K-5383, supplementary file S1) whereas charcoal from Storø (Fig. 1) indicates a mid-Kongemose culture age (K-5324, supplementary file S1). These data acquired by archaeologists provided the first information on Holocene sealevel changes.

In 2014, Geopark Odsherred was established as a UNESCO Global Geopark (Jakobsen et al. 2015). The inner part of Lammefjorden is included in the geopark. To further develop the record of Holocene sea-level change of the former fjord using modern techniques, four sediment cores from the area were collected (cores 197.670-73) in 2016, and in 2017 other seven cores were collected, including 197.77 and 197.79 reported here (Fig. 1). In 2017, georadar data were also collected. This work was reported in unpublished (non-peer reviewed) reports in Danish by Jakobsen et al. (2016) and Jakobsen \& Bennike (2017). Here, the results for an international audience are presented, along with new descriptions and sampling of open sections studied in 2019 (sites A/B in Fig. 1). In total, 86 samples were analysed for macrofossils, and 12 samples of macrofossils were submitted for radiocarbon dating. The sampling locations are shown in Fig. 1 and methods are provided in an online supplementary file.

\section{Results}

\section{Long cores}

Simplified sedimentological core logs for six cores are shown in Fig. 2, and macrofossil data are shown in supplementary file S2. Core sites were chosen to provide long records. Core 197.670 was 13.8 m long and consisted of clayey till overlaid by two units of glaciofluvial sand. The upper sand unit contained rare remains of, for example, Dryas octopetala, Betula nana and Distichium sp., which indicate an environment with dwarf-shrub heaths of Late Glacial age. A similar fossil assemblage from core 197.671 was dated to 13.9 cal. ka (see below).

The Late Glacial sediments are overlaid by marine and brackish-water gyttja with shells of, for example, Mytilus edulis, Cerastoderma sp., Hydrobia sp., Bittium reticulatum, Balanus crenatus and Cyprideis torosa (ostracode). The faunas indicate a marine environment with moderate salinity. Mytilus and Balanus need firm substrates. A sample from the base of the marine mud was dated to $2.5 \mathrm{cal}$. ka. If sedimentation continued till the area was reclaimed, it means that $10 \mathrm{~m}$ of gyttja was deposited in $2.5 \mathrm{ka}$, corresponding to a high mean sedimentation rate of $4 \mathrm{~mm} / y e a r$. With only one date, this sedimentation rate is obviously highly uncertain.

Core 197.671 was $25 \mathrm{~m}$ long and consisted of till overlain by clay, silt and sand with abundant shells of the small crustacean Alona sp. and rare remains of chironomids and Cristatella mucedo. These species indicate a lacustrine environment. Land plants were mainly represented by Betula sect. Albae. One sample from $26.75 \mathrm{~m}$ b.s.l. contained remains of Betula nana, Dryas octopetala, Distichium sp., Hippuris vulgaris and Aulacomium palustre. 


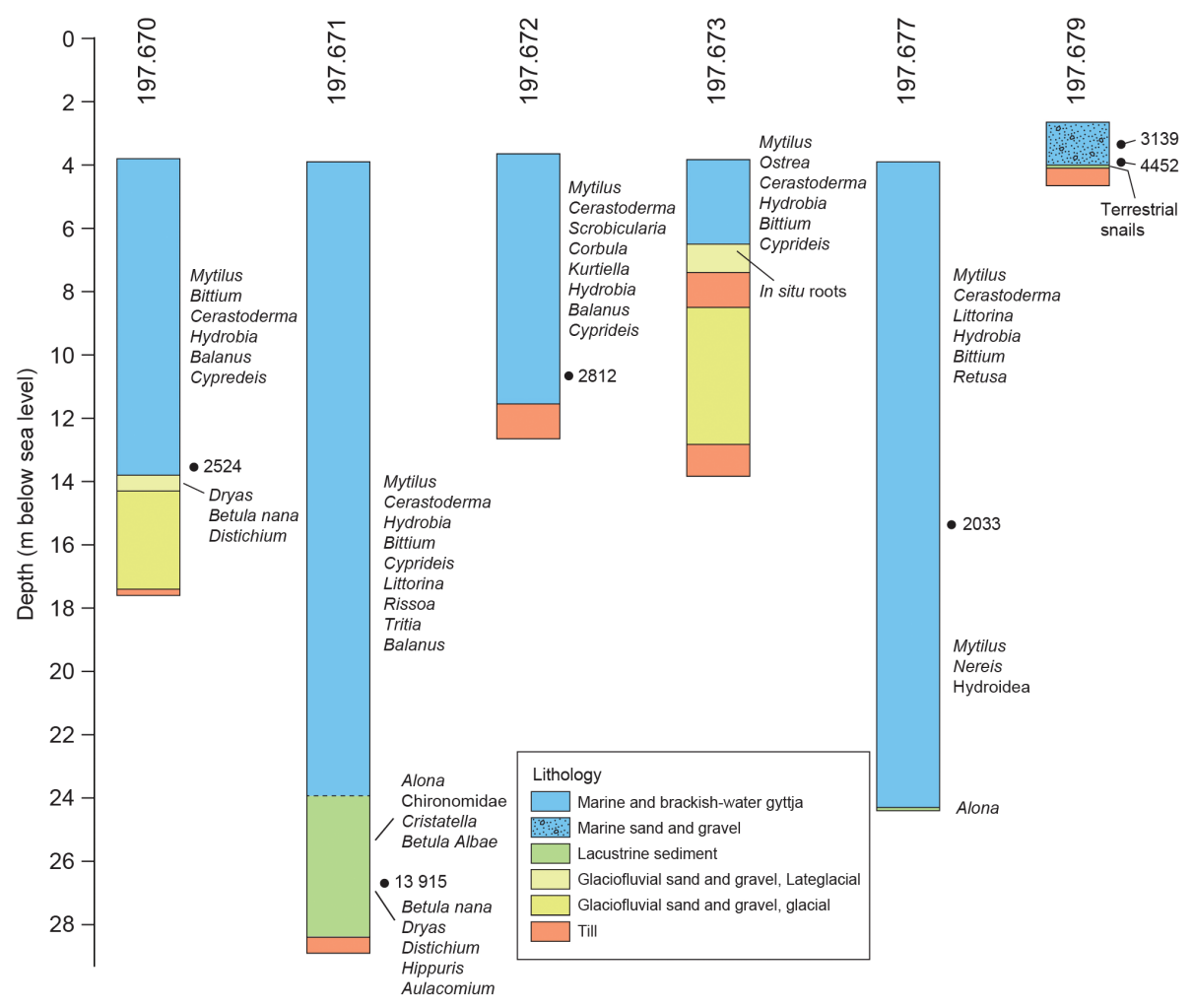

Fig. 2 Simplified sedimentological core logs from Lammefjorden. Further details on sediments are available at http://www.geus.dk/ produkter-ydelser-og-faciliteter/ data-og-kort/national-boringsdatabase-jupiter/. The ages show median calibrated ages in years before the present (BP).

A sample from this level was dated to 13.9 cal. ka. Alona indicates lake environment and land plants indicate Late Glacial age (11.7-14.7 cal. ka), as confirmed by ${ }^{14} \mathrm{C}$ dating. The lake sediments are overlaid by marine gyttja with shells of Mytilus, Cerastoderma, Hydrobia sp., Bittium reticulatum and Cyprideis torosa as well as rare remains of Littorina littorea, Rissoa parva, Tritia reticulata and Balanus crenatus.

Core 197.672 was $9 \mathrm{~m}$ long, with clayey till at the base and $7.4 \mathrm{~m}$ marine gyttja with Mytilus, Cerastoderma, Scrobicularia plana, Corbula gibba, Kurtiella bidentata, Hydrobia sp., Balanus crenatus and Cyprideis torosa. A shell sample near the base yielded an age of $2.8 \mathrm{cal}$. ka, indicating a mean sedimentation rate of $2.4 \mathrm{~mm} /$ year.

Core 197.673 was $10 \mathrm{~m}$ long. The lower part of the core contained till and glaciofluvial sediments with in situ roots of land plants. The upper part consisted of gyttja with macrofossils that comprise Mytilus, Ostrea, Cerastoderma, Hydrobia sp., Bittium reticulatum and Cyprideis torosa.

Core 197.677 was $20.5 \mathrm{~m}$ long. The core contained sandy silt with Alona sp. at the very bottom, interpreted as Late Glacial lake sediment. It is followed by $20.4 \mathrm{~m}$ marine or brackish-water gyttja. The lower part contained only scattered, rare small fragments of Mytilus, a few jaws of Nereis sp. and some skeletal remains of hydroids. Shells become more frequent at c. $15.5 \mathrm{~m}$ b.s.l. and the upper half of the core comprised Mytilus, Cerastoderma, Littorina littorea, Hydrobia sp., Bittium reticulatum and rare Retusa truncatula. A sample from
$15.6 \mathrm{~m}$ b.s.l. is dated to $2.0 \mathrm{cal}$. ka, indicating a very high mean sedimentation rate of nearly $6 \mathrm{~cm} / y e a r$. With only one date, this sedimentation rate is obviously highly uncertain as mentioned above.

\section{Georadar data and a short $2 \mathrm{~m}$ core}

Georadar profiling was carried out at two sites with oyster banks (Fig. 3). At the first site (profile 1), the elevation increases from $4 \mathrm{~m}$ b.s.l. in the west to $1.3 \mathrm{~m}$ b.s.l. in the east. In the east, with no penetration, clayey till was found by coring. The eastern part of the profile was followed by a $20 \mathrm{~m}$ long section with strong reflectors. Coring revealed alternating layers of shells and sand, followed by gravelly sand and clayey till. In the western part of the profile, the penetration depth of the radar signal was only c. $1 \mathrm{~m}$ and the reflectors were weak. The internal structures show progradation to the west. Coring showed fine-grained sand, silt and gyttja with marine shells in this area.

At the second site, profile 2, numerous marine shells occurred on the terrain surface. In the westernmost part of the profile, with almost no penetration, coring revealed clayey till. The rest of the profile showed relatively strong reflectors, which mark layering with two shell banks. Core 197.679 was collected in the western structure, it was $2 \mathrm{~m}$ long with clayey till at the base, followed by organic sediments with shells of terrestrial snails (Carychium tridentata, Vallonia costata, Vertigo pusilla and Vitrea contracta; Fig. 2 and supplementary file S2). This was followed by sand and gravel with shells of 


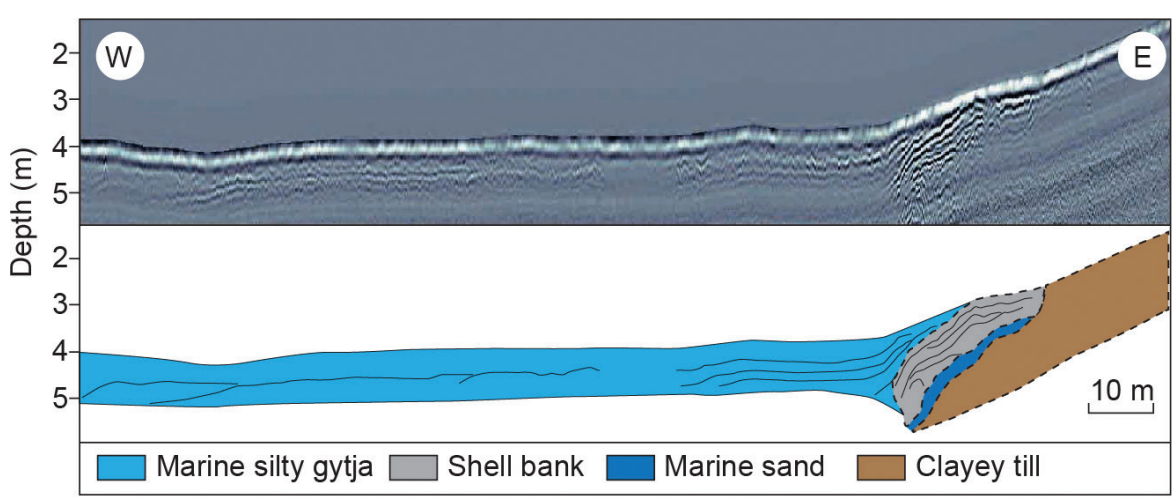

Profile 1

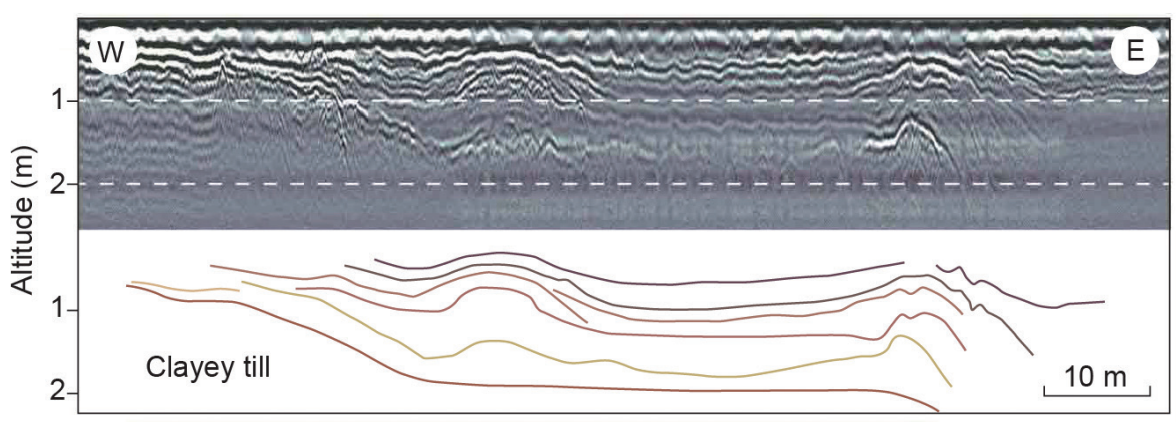

Profile 2
Fig. 3 Georadar profiles with interpretation below. The depth scale for profile 1 is in metres below sea level ( $\mathrm{m}$ b.s.l.). Profile 1 is located at $\mathbf{G R}$ shown in Fig. 1, and profile 2 at $\mathbf{6 7 9}$ in Fig. 1. marine species. The fauna comprised abundant shells of Mytilus and Balanus crenatus, common shells of Ostrea edulis and Bittium reticulatum and rare shells of, for example, Cerastoderma sp., Tritia reticulata and Buccinum undatum. Two samples were dated, one at the base of the shell-rich bed and another at the top. The ages of the samples were c. 4.5 and $3.1 \mathrm{cal}$. ka.

\section{Open sections}

Two open sections were studied in 2019 (sections A and B; Fig. 1), located $400 \mathrm{~m}$ apart. The results are summarised in supplementary files S3 and S4. The lowermost sediments at site A (7 m b.s.l.) consisted of lake marl with shells of fresh-water molluscs such as Valvata sp., Bithynia tentaculata, Radix peregra, Acroloxus palustris and Pisidium sp., statoblasts of Cristatella mucedo. Remains of the water plants Chara sp., Nymphaea alba and Potamogeton natans, the reed plants Phragmites australis and Cladium mariscus and the land plants Betula sect. Albae and Pinus sylvestris were also found. Two samples were dated to c. 10.3 and 10.6 cal. ka (supplementary file S1). The marl was overlain by coarse-grained detritus gyttja at $6 \mathrm{~m}$ b.s.l. with remains of the water plants Nymphaea alba, Potamogeton natans and Najas marina, the reed plants Schoenoplectus lacustris and Cladium mariscus, and the land plants Betula sect. Albae and Pinus sylvestris. A sample from this layer was dated to $8.8 \mathrm{cal}$. ka. Najas marina and Cladium mariscus are rare in Denmark today, but they were common in the Early Holocene (Bennike et al. 2004). The lake sediments were overlaid by a layer rich in shells of marine molluscs at 5.5 $\mathrm{m}$ b.s.l.. The fauna included Ostrea, Mytilus, Bittium reticulata and Tritia reticulata. The largest Ostrea shell was $105 \mathrm{~mm}$ long and dated to c. 6.2 cal. ka. Finally, a non-in situ root of Pinus from $6.5 \mathrm{~m}$ b.s.l. from the section was dated to 9.9 cal. ka.

At site B, a sample of forest peat from $7 \mathrm{~m}$ b.s.l. mainly consisted of twigs and wood fragments with many bark fragments of Pinus sylvestris and a few sclerotia of the fungus Cenococcum geophilum (supplementary file S3). A sample of Pinus sylvestris bark fragments yielded an age of c. 9.8 cal. ka (supplementary file S1).

\section{Discussion}

Based on the cores described here, it is clear that there was an at least $20 \mathrm{~m}$ deep basin in the inner western part of Lammefjorden. We suggest that it formed as glacier bulldozed material into the arc-shaped hilly area west of Lammefjorden, as first proposed by Rørdam \& Milthers (1900).

Sjælland was de-glaciated about 18000 to 16000 years ago (Houmark-Nielsen et al. 2012), but it apparently took several millennia before plants immigrated to the region. We obtained an age of c. 13.9 cal. ka the oldest plant remains so far dated from the region. However, older samples, up to c. 15.2 cal. ka, have been dated from offshore areas close to Sjælland (Bennike 
\& Jensen 1995; Bennike unpublished data). The fossil assemblages indicate a tree-less open tundra-like vegetation with dwarf-shrub heaths.

In the Early Holocene, Lammefjorden was probably covered with lakes, bogs and forests. In the Mid-Holocene, the sea transgressed low-lying parts of Odsherred, and Lammefjorden was formed. The oldest age of marine shells from Lammefjorden is c. 6.7 cal. ka, providing a minimum age for initial marine transgression. The age is at least 1000 years younger than expected when compared with other dated samples from the region (Olsen et al. 2009; Bennike et al. 2017). However, dating more samples might produce older ages. It is also possible that there is a shallow threshold to the inner part of Lammefjorden, which prevented marine waters from flooding the area earlier. During the Mid-Holocene, marine faunas with large Ostrea edulis indicate higher salinities and summer temperatures than at present and likely a larger tidal amplitude. In the Mid-Holocene, the RSL in the region was c. $3.5 \mathrm{~m}$ higher than at present, which would also lead to rich marine faunas.

Samples from several cores collected from deep basins in this study contained species-poor faunas. Several explanations are offered but we consider high or very high sedimentation rates as the main cause. High sedimentation would have meant turbid water, making life difficult for benthic invertebrates.

A shell bank dominated by Mytilus and Ostrea gave ages of 4.5 and 3.1 cal. ka. Several hundred samples of Ostrea shells from Denmark have been dated and the ages show a peak of about $6.0 \mathrm{cal}$. ka (Bennike et al. 2017). The common presence of the species in Lammefjorden at a much later stage is surprising. The species immigrated to Denmark in the Early Holocene and today it is absent from the inner Danish waters (Bennike et al. 2017).

In supplementary file $\mathrm{S} 5$, ages of macrofossils versus depth are plotted. Note that these samples were collected from a large area (c. $50 \mathrm{~km}^{2}$ ) with slightly different isostatic uplift rates. Also plotted are global eustatic sea-level changes (Lambeck et al. 2014) and a RSL curve for the Marthe Flak region (Bennike unpublished data), located in an area with a similar marine limit to Lammefjorden. As expected, the marine samples are plotted below the RSL curves. Most of the terrestrial and lacustrine samples are located far above the curve, indicative of lakes and bogs that existed in the area long before the marine transgression. Two samples (K-5308 and K-5996) appear to represent material that was formed just before the marine transgression. One sample of charcoal (K-5383) plots below the curve, indicating it was reworked. Finally, K-3781 appears far below the curve. This sample, which comes from a 10 m long Quercus stem, could have floated to the site and sank in deep water.

\section{Conclusions}

Late Glacial and Holocene lake and bog deposits occur below the marine deposits in the reclaimed Lammefjorden. Marine gyttja in some basin areas show potentially high sedimentation rates, which led to locally sparse benthic faunas. Obtaining more radiocarbon dates would further constrain these sedimentation rates. In other areas, rich marine mollusc faunas were found, with large Ostrea edulis, indicative of high summer temperatures, salinity and strong tidal currents. A marine shell at 6.7 cal. ka provides a minimum age for the marine transgression of Lammefjorden.

\section{Acknowledgements}

We thank two reviewers (Jonathan Lewis from Loughborough University, UK and another anonymous reviewer) for their constructive and positive reviews of the manuscript.

\section{Additional information}

Funding statement

This study was supported by Geopark Odsherred.

Author contributions

OB: macrofossil analyses, manuscript writing. PRJ: field work and reporting on lithostratigraphy and georadar data. JWH: editing.

Additional files

Additional files are available online: https://doi.org/10.34194/geusb. v44.4630

\section{References}

Bennike, O. \& Jensen, J.B. 1995: Near shore Baltic Ice Lake deposits in FakseBugt, southeast Denmark. Boreas 24, 185-195. https://doi. org/10.1111/j.1502-3885.1995.tb00772.x

Bennike, O. et al. 2004: Late- and postglacial history of the Great Belt, Denmark. Boreas33,18-33. https://doi.org/10.1111/j.1502-3885.2004. tb00993.x

Bennike, O., Pantmann, P. \& Aarsleff, E. 2017: Holocene development of the Arresø area, north-east Sjælland, Denmark. Bulletin of the Geological Society of Denmark 65, 25-35.

Christensen, C. 1994: Lammefjorden. Undersøgelser på fire lokaliteter ifjorden giver informationer om havniveauændringer og afkræfter formodet forekomst af tektoniske bevægelser af landjorden i atlantisk tid. NNU Rapport 19994(16), 31 pp.

Christensen, C. \& Andreasen, E.A. 1999: Strandforskydning i Nordvestsjælland i atlantisk ogsubboreal tid. NNU Rapport 19992(2), 19 pp.

Houmark-Nielsen, M. et al. 2012: Cosmogenic surface exposure dating the last deglaciation in Denmark: discrepancies with independent age constraints suggest delayed periglacial landform stabilisation. Quaternary Geochronology 13, 1-17. https://doi. org/10.1016/j.quageo.2012.08.006

Jakobsen, P.R. \& Bennike, O. 2017: Geologisk model for Lammefjordens inderlavning. Danmarks og Grønlands Geologiske Undersøgelse Rapport 2017/39, 41 pp.

Jakobsen, P.R. et al. 2015: Geopark Odsherred. Danmarks føste geopark. Geoviden 2015(1), 20 pp.

Jakobsen, P.R. et al. 2016: Boringer i Lammefjordens inderlavning. Danmarks og Grønlands Geologiske Undersøgelse Rapport 2016/41, 32 pp. 
Lambeck, K. et al. 2014: Sea level and global ice volumes from the Last Glacial Maximum to the Holocene. Proceedings of the National Academy of the United States of America (PNAS) 111, 15296-15303. http:// www.pnas.org/cgi/doi/10.1073/pnas.1411762111

Madsen, A.P. et al. 1900: Affaldsdynger fra Stenalderen i Danmark: Undersøgte for Nationalmuseet, 196 pp. Copenhagen: C.A. Reitzel.

Mertz, E.L. 1924: Oversigt over de sen- og postglaciale Niveauforandringer i Danmark. Danmarks Geologiske Undersøgelse II. Række, 41, 49 pp.

Olsen, J., Rasmussen, P. \& Heinemeier, J. 2009: Holocene temporal and spatial variation in the radiocarbon reservoir age of three Danish fjords. Boreas 38, 458-470. https://doi.org/10.1111/j.1502-3885. 2009.00088.x
Rørdam, K. \& Milthers, V. 1900: Beskrivelse til geologisk kort over Danmark. Kortbladene Sejrø, Nykøbing, Kalundborg og Holbæk. Danmarks Geologiske Undersøgelse I. Række, 8, 132 pp.

Simonsen, P. 1946: Stenalderbopladsen i Gislinge Lammefjord. Historisk Årbog for Holbæk Amt 1946, 38-61.

Troels-Smith, J. 1942: Geologisk datering af Dyrholm-Fundet. In: Mathiassen, Th., Degerbøl, M. \& Troels-Smidt, J. 1942: Dyrholmen. En stenalderboplads på Djursland. Det Kongelige Danske Videnskabernes Selskab, Arkæologisk-Kunsthistoriske Skrifter 1(1), 212 pp.

Westerby, E. 1933: Nogle Stenalderfund fra tørlagt Havbund. Meddelelser fra Dansk Geologisk Forening 8, 231-248. 